p-ISSN: 2088-6991

e-ISSN: $2548-8376$

June 2021
Tarbiyah: Jurnal Ilmiah Kependidikan

Vol. 10 No. 1 January - June $2021(35-43)$

DOI: http://dx.doi.org/10.18592/tarbiyah.v10i1.4410

\title{
THE DEVELOPMENT OF ANDROID-BASED ISLAMIC EDUCATION LEARNING MEDIA
}

\author{
Ahmad Maulani $^{1 *}$, Sovia Mas Ayu ${ }^{2}$, Oki Dermawan ${ }^{3,}$ Muhammad Akmansyah ${ }^{4}$ \\ 1,2,3,4 Islamic Education Department, Postgraduate, \\ Universitas Islam Negeri Raden Intan, Lampung, Indonesia \\ *Email: madlaney92@gmail.com
}

Website: http://jurnal.uin-antasari.ac.id/index.php/jtiik

Received: 22 January 2021; Accepted: 3 June 2021; Published: 24 June 2021

\begin{abstract}
The purpose of this study was to develop instructional media, describe the feasibility of learning media, describe the response of android media users, and describe the effectiveness of Android-based learning media on Islamic Education subjects. The type of the research was $\mathrm{R} \& \mathrm{D}$ with the ADDIE development model. This study took the subject of educators and $10^{\text {th }}$ graders at Darussalam Sumberejo Vocational School Tanggamus Lampung. Data collection used questionnaires and interviews. The results showed that the Android-based Islamic education learning media named Islamuna was suitable for general use and was effective in improving student learning outcomes. The increase in student learning outcomes can be seen in the pretest and posttest scores with an average of 68.5 and 81.33.
\end{abstract}

Key Words: android; learning outcomes; Islamic education media

\section{INTRODUCTION}

The increasing of science and technology development has caused almost all human activities to be controlled by science and technology. A smartphone is one of communication media based on android which is very popular in all circles of society and at all ages, both adults, teenagers, and children, and even students. The function of the media is a tool that use to deliver a message from sender to recipient. At the time of learning takes place, teachers and students as senders and recipients of the message. The existence of the media can be used as a means of liaison between teachers and students.

Learning media has its purpose as a device to facilitate the learning process in the classroom. In addition, the media can also make the learning process more efficient and can increase the concentration of students, Astuti (2017).

The existence of media in the learning process makes the ambiguity of the material presented easier. According to (2014: 14) the learning media is a device that is used as an intermediary from the information source to the information recipient such as video, TV, computer, and many others. This is in line with Widiastusti (2018: 288) which states that the learning media is a tool in the form of physical and non-physical which is used as an intermediary between educators and students in understanding learning material.

Bringgs in Adam dan Syastra (2015: 79) also states that media is all physical tools that can present messages and stimulate students to learn, for example, books, films, cassettes.

The learning media used by educators currently lack creativity and innovation, so students tend to be bored and less interested in the learning process. This is based on the author's observations of several schools, namely Darussalam Vocational School, Bina Technology Vocational School, and Sumberejo 1 Senior High School.

The researchers conducted interviews with students of Darussalam Sumberejo Vocational School and obtained 
the results that students were less motivated in the learning process because the learning process carried out by educators was less attractive and educators only gave assignments through the Whatsapp Group during online learning and collected them through the Whatsapp Group. Since learning is carried out from home, educators carry out learning through online media such as Whatsapp, google meet, google form, zoom and so on which can be accessed via android. In Darussalam Vocational School, only some students take part in the online learning process so that students are less enthusiastic in participating in the learning process.

In addition, researchers also conducted observations and interviews with 10th graders at Darussalam Vocational School. The results of the interviews of researchers with students stated that when the learning process took place, the Islamic Education subject teachers never used media during the learning process in class so that learning was less interesting and bored when learning took place.

The results of observations and preresearch interviews at SMK Darussalam conducted by researchers to educators in the field of study at SMK Darussalam obtained that educators only use blackboard media and PowerPoint and WA groups when online, educators have not used Android media in the form of applications in the Islamic Education learning process.

Observation and interviews conducted at Bina Teknologi Vocational School Sumberejo found that in the learning process educators often only use textbooks, whiteboards and PowerPoint when face to face. Likewise, Sumberejo 1 Senior High School educators only use learning media in the form of books, blackboards, the surrounding environment and LCD projectors during Islamic Education learning, so that the learning carried out seems monotonous because the media used is less effective and does not attract the interest and attention of students.
In addition to this, the researchers also conducted observations at Darussalam Sumberejo Vocational School and Darussalam Sumberejo Vocational School did not use Android-based learning applications yet during online learning so that supporting facilities are needed such as Android-based learning applications that can be accessed online. Moore et al in Handarini (2020) state that online learning is a learning activity that requires an internet network with connectivity, accessibility, flexibility, and the ability to bring up various types of learning interactions.

Development research carried out by researchers in addition to containing Islamic Education material, students can also access Islamic articles and media developed in the form of android applications that are synergized with other features found on Android such as Islamic Education applications that can be changed by the teacher, Islamic article features, information, downloaded books, assignment collection schedules, online google meet and the use of google drive as an evaluation of student learning outcomes and to collect assignments, which are packaged in one application so that the learning process is more effective and efficient for both teachers and students. Thus this android application can be used in online and face-to-face learning in Islamic Education subjects at the high school level. The use of mobile technology has a major contribution in educational institutions, including the achievement of distance learning goals, Korucu \& Alkan in Sadikin (2020).

Based on this description, researchers are interested in conducting research on the development of androidbased learning media where teachers and students can access it online by utilizing android-based application software so that Islamic Education learning that will be carried out is more creative, innovative, comprehensive, and follows current trends. 
This Learning Media will make it easier for educators to deliver material and students when receiving material due to the COVID-19 situation. Learning can be carried out from home and can be carried out anytime and anywhere so that educators are easier to explore in teaching Islamic Education. Based on the explanation above, the researchers are interested in conducting research by developing it with the title "Development of Android-Based Islamic Education Learning Media".

The purpose of this study is to develop android-based Islamic Education learning media, to describe user responses to the developing learning media, the feasibility of android-based learning media and the effectiveness of android-based learning media to Islamic Education subjects.

Zulkifli (2013: 24) states that Islamic Education is expected to produce humans who always try to improve faith, piety and morals, and are active in building civilization and harmony in life, especially in advancing a dignified civilization.

Saraubon (2016: 52-59) explained that Android currently has a very important role in modern society around the world, Android technology has a very important role in the world of education which is a powerful tool that can be used for the learning process inside and outside the classroom, students and educators use Android technology. for various teaching and learning purposes.

While Astra (2015) also stated that Android is a mobile operating system that grows in the midst of other operating systems that are developing. Android is a comprehensive open source platform designed for mobile devices. Android is a Linux-based operating system for mobile devices. Furthermore, Murtiwiyati in Kuswanto (2018) revealed that Android is an operating system for Linux-based mobile devices that includes an operating system, middleware and applications. Android is one of the operating systems that are in great demand by the public because it has advantages such as being open source which provides flexibility for developers to create applications.

\section{RESEARCH METHOD}

This research uses a mixed-methods approach, in which the research methods are carried out by combining two qualitative and quantitative approaches in order to obtain more comprehensive data, Sugiono (2011: 404). The method used by the researchers is the $\mathrm{RnD}$ research method. The RnD method is a research method used to produce/develop certain products, as well as to test the effectiveness of these products in a study. To be able to produce certain products used research that is needs analysis to test the effectiveness of these products. The research was carried out in stages/longitudinal so that the results of these products could be useful for users of the wider community, Sugiyono (2011: 297).

According to Hanafi (2017: 130131) $\mathrm{RnD}$ is a research method that aims to produce certain products and test the validity and effectiveness of these products in their application. The development model used in this study is the Borg \& Gall development model, but during implementation, the researchers switched to the ADDIE model, because the ADDIE model was easier and simpler. The stages of research using the ADDIE model can be seen in the figure below.

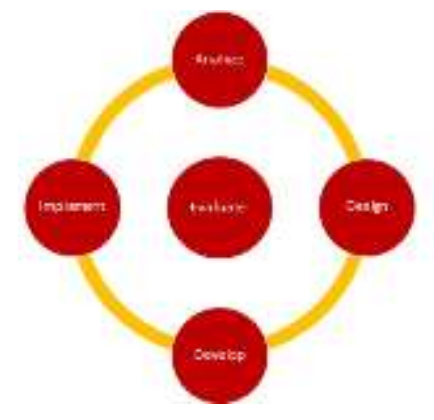

Figure 1. ADDIE Development Model

The stages of research carried out using the ADDIE development model are a 
development model consisting of 5 stages (Analyze, Design, Develop, Implement, Evaluate). The subjects of this study were students of class X SMK Darussalam Argomulyo. The data collection techniques and instruments used in this study were interview guides, questionnaires and observations.

This study used data analysis in the form of descriptive verbal data which was analyzed qualitatively. While quantitative analysis is used to analyze expert test data, practitioner test and field test. Data processing is done by using the percentage formula. T-test analysis was used to see the difference in learning outcomes from before using the media and after using the media.

\section{RESULTS AND DISCUSSION}

\section{Analysis}

The needs analysis carried out in the study includes 3 things, namely user needs analysis, content/material needs analysis, hardware and software requirements analysis. Analysis of user needs is carried out to determine user needs supported by specifications/characteristics of learning media, namely the target user of class $\mathrm{X}$ students at Darussalam Sumberejo Vocational School, APHP and Multimedia Department, the type of learning media to be developed is an Android-based Islamic Education learning media development model with the features needed are learning materials, attendance menu for online learning, online test menu, task gathering menu and other menus that support the online learning process.

Analysis of content / material, researchers chose the material in this study is the procedure for dressing in accordance with Islamic sharia with sub-fields of morality. The selection of this material is due to the observation that students' dress code is often impolite, not included and not clean when at school. In addition to this, students when they return home do not wear a headscarf and wear clothes that reveal their genitals and wear veiled and closed clothes only when at school or at the Al-Qur'an. Besides that, researchers also have their own reasons that how to dress is the identity of a Muslim because someone's clothes reflect that person's behavior.

While the analysis of hardware and software in this study, the software used is google chrome or opera to access the CPanel to build websites and the App Builder to make the designs we make into an attractive application and can be used for online learning during the covid-19 period. To run the software, no hardware or hardware with high specifications is needed, such as making applications in general, as long as they are able to access the internet.

\section{Design}

Design is the second stage in the development of learning media. The result of the design phase is a flowchart that describes the sequence and structure of the learning media. The flowchart that has been made is then used as a guide for designing storyboards so that a planning design is produced that is in accordance with the media structure. The storyboard in this development contains the design of making media which includes buying a domain and hosting, building a website through wordpress through installation in c-panel, registering \& login app builder, defining Islamuna application template, then creating application menu.

\section{Development}

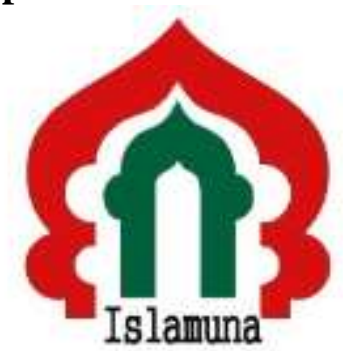

Figure 2. Islamuna Icon App

The figure is the name of the application and can be downloaded via the Playstore application on Android with the 
keyword "Islamuna" select the application according to the logo above, because in the Playstore there are several Islamuna applications with the same name, only different functions and uses. In Figure 2 there is the first display when clicked on the Islamuna application before heading to the dashboard sheet on the Islamuna application.

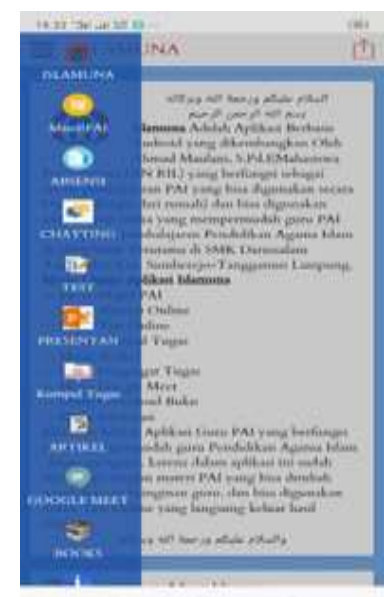

Figure 3. Menu Display

Figure 3 is a display of all the menus contained in the Islamuna application consisting of a dashboard, pie material menu, attendance menu, online test menu, chat menu, task gathering menu, article menu, and information menu.

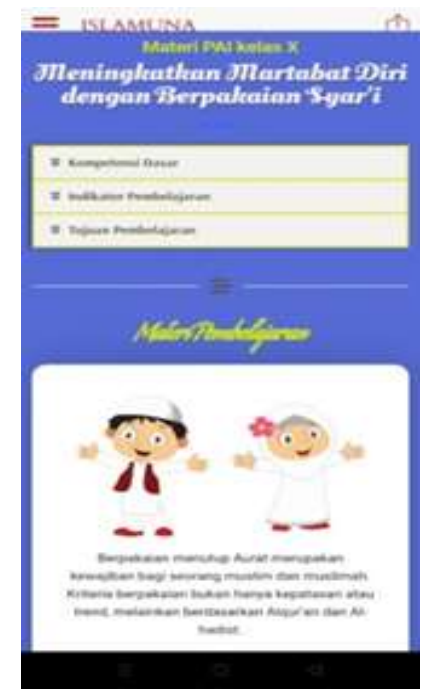

Figure 4. Material Menu Display
Figure 4 is the main menu of the Islamuna application because in this menu there is material content from the Islamuna application about dress code based on Islamic sharia, on the pie material menu at the top there is the title of the material and below it there are basic competencies (KD), learning indicators and learning objectives.

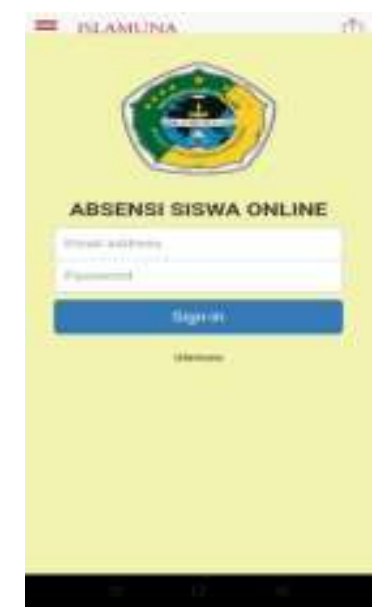

Figure 5. Attendance Display

Figure 5 is an online attendance menu that can be accessed and used by students when learning online so that students can also remain absent even though online learning is carried out, and teachers can also monitor student activity in the online attendance.

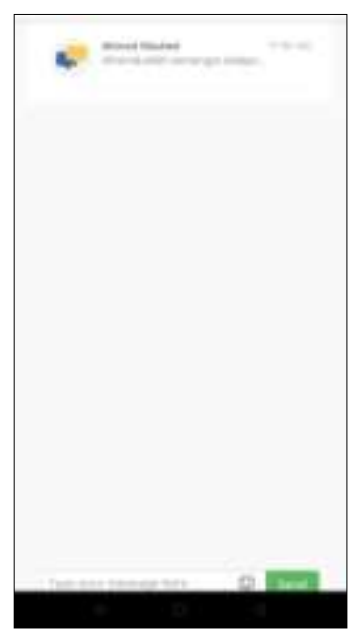

Figure 6. Chatting Menu Display

Figure 6 shows the Chat menu which functions as a place for students to communicate with classmates and with the 
subject teacher during the learning process and the chat menu can also be used for discussion of lessons delivered by the subject teacher so that learning is more interactive in the online learning process.

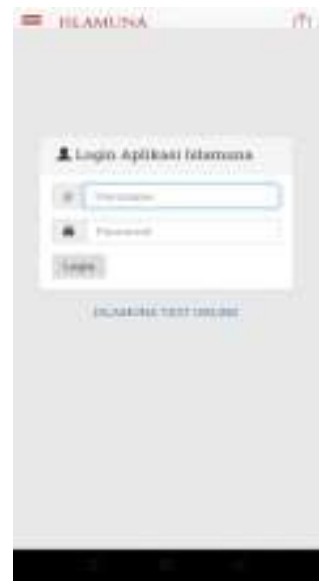

Figure 7. Online Test Menu Display

In Figure 7 there is an online test menu that is useful for assessing Islamic Education learning outcomes which can be directly seen by educators and students when they finish working on online test questions. the function of this online test is that it is easier for teachers to assess learning outcomes because in online learning educators are required to be creative in using learning media so that learning is more interesting and easy to do because it is not face-to-face in class.

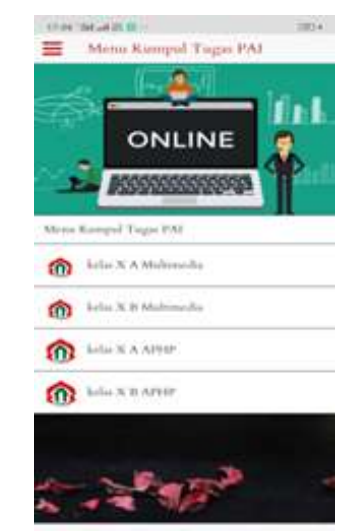

Figure 8. Task Menu Display

Figure 8 is a task collection menu that can be accessed by students using Google Forms so that the results of the assignments can be stored in the Google Drive folder. This makes students do not need to access the App browser to open google forms.

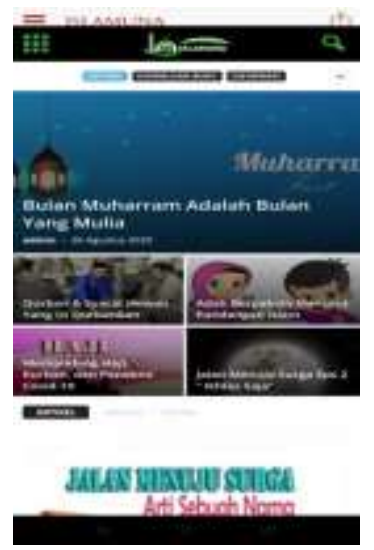

Figure 9. Islamic Article Menu Display

In this menu, students can add scientific articles related to Islam such as Islamic articles in the Islamuna application and connected to the https://Islamuna.my.id website.

\section{Implementation}

\section{a. Media Expert Validation}

The results of the calculation of the percentage of the two validators obtained values of $88.5 \%$ and $77.1 \%$. This learning media development product is in a very feasible qualification, meaning that this product is considered suitable for use in the field even though there are several things that need to be improved. Criticisms and suggestions given by media experts will be taken into consideration for product improvement.

\section{b. Content Expert Validation}

The material used in this study only focuses on class X material, namely the material for Dressing in Islamic Shari'a. The results of the calculation of the percentage of the two validators obtained the value of $75 \%$ and $83.3 \%$. This learning media development product is in a very feasible qualification, meaning that this product is considered suitable for use in the field even though there are several things that need to be improved. Criticisms and suggestions given 
by content experts will be taken into consideration for product improvement.

\section{c. Language Expert Validation}

The results of the calculation of the percentage of linguists obtained a value of $81.82 \%$, from 2 validators obtained a value of $75 \%$ and $83.3 \%$. This learning media development product is in a very feasible qualification, meaning that this product is considered suitable for use in the field even though there are several things that need to be improved. Criticisms and suggestions given by linguists will be taken into consideration for product improvement.

\section{d. Field Trial}

The results of small-scale field trials conducted on 10 students received a very good response. This can be proven by the figure below.

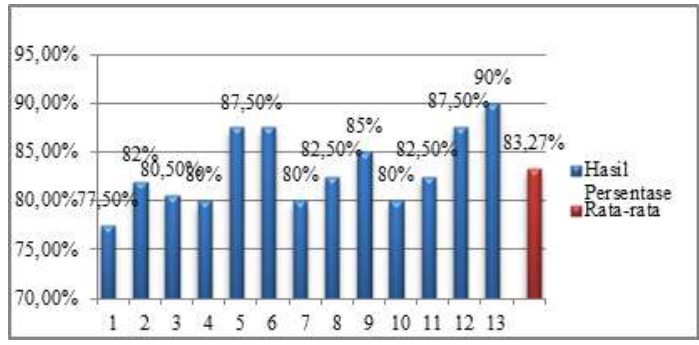

Figure 10. Small-Scale Trial Results

Based on the picture above, it can be seen that the average value of the percentage given by students is $83.27 \%$. So in general this Islamic Education media is very suitable to be used in the learning process.

While the results of large-scale tests conducted on 38 students by researchers in the field got a very good response as well. This can be proven by the figure below.

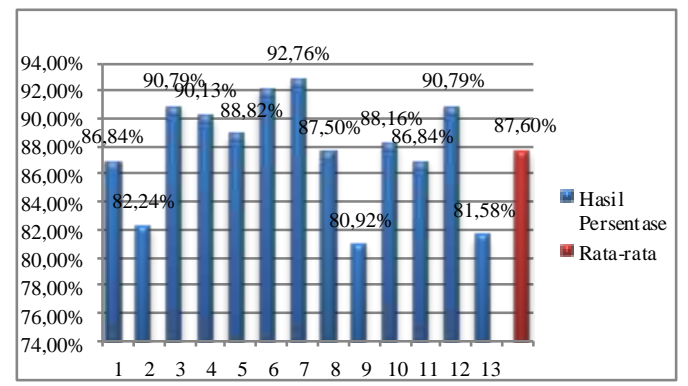

Figure 11. Large-Scale Trial Results
Based on the picture above, it can be seen that the average percentage value given by students is $87.60 \%$. Based on this description, the Islamuna media developed by this researchers was declared very suitable for general use in Islamic Education learning and did not require further revision.

\section{e. Data Analysis}

Student learning outcomes before and after using android-based learning media obtained an average value of 68.50 , while student learning outcomes after using android-based learning media obtained an average value of 81.33. Based on this description, it can be seen that there is an increase in the average score of students after using Islamuna media with an average difference of 12.16 .

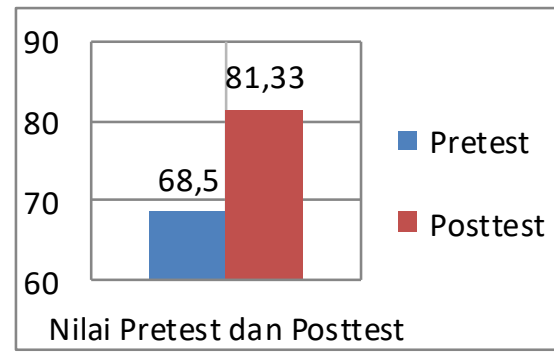

Figure 12. Pretest and Posttest Score

Data analysis uses a T-test. It can also be seen that the significance level is 0.000 , $<0.05$, it is stated that there is a significant difference in results. Based on the data obtained, it can be concluded that the use of android-based learning media developed by researchers is effective in improving learning outcomes of 10th graders Darussalam Vocational School Argomulyo during the covid-19 period.

\section{Evaluation}

Evaluation is carried out as a basis for improving the product. Evaluations from media experts include adding a chat menu to the application, improving the attendance format, the colors on the display are more varied and the figures contained in the application are adjusted to the age of the research subject. Evaluations from material 
experts include the addition of literacy to the material and improvements to the writing system contained in the evaluation questions. And evaluations from linguists include improving the writing of capital letters and hyphens. In the small-scale trials that have been carried out, the responses from students are very good and do not require further revision so that they can be continued to the large-scale trial stage.

The supporting factor in this research is online learning which requires applications that educators can use to transfer knowledge. While the inhibiting factor in this research is the internet network which is sometimes unstable because this application can only be used when Android is connected to the internet network.

This Islamuna application has several advantages including an attractive layout display, easy to use and lightweight during installation, can be downloaded via the Playstore application, can be developed and entered into E-learning, the subject matter can be changed at any time via a PC or laptop, using source code PHP for system management for attendance and evaluation tests, equipped with a chat application and can be installed on any type of android.

This Islamuna application has several advantages including an attractive layout display, easy to use and lightweight during installation, can be downloaded via the Playstore application, can be developed and entered into E-learning, the subject matter can be changed at any time via a PC or laptop, using source code PHP for system management for attendance and evaluation tests, equipped with a chat application and can be installed on any type of android.

\section{CONCLUSION}

Based on the description above, it can be concluded that this android-based learning media (Islamuna) is feasible to be used in general and is effective in improving student learning outcomes in online learning or learning done from home. From the results of the validation of media experts and material experts, this media was declared feasible to be used in the online learning process. The results of the validation test of the two media experts got percentage values of $88.5 \%$ and $77.1 \%$. The results of the validation of the two material experts obtained a score of $75 \%$ and $83.3 \%$. While the test results of linguists obtained a value of $82.87 \%$.

Small-scale field trials conducted by 10 students and female students obtained a percentage of $83.27 \%$ and reliable so there is no need for a second revision. While the large-scale trials conducted by 38 students and class $\mathrm{X}$ students obtained a percentage of $87.60 \%$ and reliable, which means that the product resulting from the development of this media received a very good response from students and can be used in general.

The learning outcomes of students have increased. This can be seen in the pretest and posttest scores with an average of 68.5 and 81.33. Based on the results of the T-Test analysis, it was concluded that the learning outcomes of the 10th graders in Islamic Education at Darussalam Vocational School conducted by researchers using android-based learning media (Islamuna) obtained significant differences. This means that the learning outcomes of students before and after using android-based learning media (Islamuna) there are positive differences and improvements in using Islamic media in the Islamic Education learning process.

\section{REFERENCES}

Adam Steffi \& Syastra Muhammad Taufiq. 2015. Pemanfaatan Media Pembelajaran Berbasis Teknologi Informasi pada Siswa Kelas X di SMA Ananda Batam. CBIS Journal, 2 (2) 78-90.

Astra, I. Made. 2015. Development of an Android Application in the Form of a Simulation Lab as Learning Media for 
Senior High School Students. Eurasia Journal of Mathematics, Science and Technology Education. https://doi.org/10.12973/eurasia.2015. $1376 \mathrm{a}$

Djamarah, Syaiful Bahri \& Aswan Zain. Strategi Belajar Mengajar, Jakarta: Rineka Cipta, 2010.

Handarini Oktavia Ika. 2020. Pembelajaran Daring Sebagai Upaya Study From Home (SFH) Selama Pandemi Covid 19. Jurnal Pendidikan Administrasi Perkantoran. 8(3) 496-503

Hanafi. 2017. Konsep Penelitian R\%D dalam Bidang Pendidikan. Jurnal Kajian Keislaman, 4 (2) 129-150.

Irnin Agustina Dwi Astuti. 2017. Pengembangan Media Pembelajaran Fisika Mobile Learning berbasis Android", Jurnal Penelitian \& Pengembangan Pendidikan Fisika, 3 (1) https://doi.org/10.21009/1.03108.

Kuswanto Joko \& Feri Radiansyah. 2018. Media Pembelajaran Berbasis Android Pada Mata Pelajaran Sistem Operasi Jaringan Kelas XI. Jurnal Media Infotama. 14 (1) 15-20.

Sadikin Ali \& Hamidah Afreni. 2020. Pembelajaran Daring Ditengah Wabah Covid 19. Jurnal Ilmiah Pendidikan Biologi. 6(2) 214-225.

Sanjaya, Wina. Media Komunikasi Pembelajaran. Jakarta: Kencana, 2014.

Saraubon. 2016. System Design of Mobile Augmented Book. International Journal of Interactive Mobile Technologies, 10 (1) 52-59, https://doi.org/10.3991/ijim.v10i1.5 276.

Setyosari, Punaji. (2013). Metode Penelitian Pendidikan dan Pengembangan. Jakarta: Kencana Prenadamedia

Sugiono. 2010. Metode Penelitian Pendidikan Pendekatan Kuantitatif, Kualitatif dan $R \& D$. Bandung: Alfabeta.
. 2011. Metode penelitian pendidikan pendekatan kuantitatif, kualitatif dan R\&D. Bandung: Alfabeta

Widiastuti, Ni Made Dian. 2018. Inovasi Aplikasi Media Pembelajaran Tari Bali Berbasis Android. Mudra Jurnal Seni Budaya, 33(2) 287-295.

Zulkifli, M. 2013. The Learning Model of Islamic Education ICT- Based at Senior High School 4 Kendari in Province of South-East Sulawesi. International Journal of Academic Research. https://doi.org/10.7813/20754124.2013/5-5/b.24 